\title{
Local knowledge and practices towards ecological restoration of a selected landscape in Atok, Benguet, Philippines
}

\author{
LEILA D. LANDICHO ${ }^{1, \bullet}$, MARIA THERESA NEMESIS P. OCAMPO ${ }^{1}$, ROWENA ESPERANZA D. CABAHUG ${ }^{1}$, \\ MARYANNE G. ABADILLOS ${ }^{1}$, RUSSEL SON A. COSICO ${ }^{1}$, ARNOLD KARL A. CASTILLO ${ }^{1}$, \\ MA. ARMIE JANICA P. RAMIREZ ${ }^{1}$, KENNETH A. LARUAN ${ }^{2}$ \\ ${ }^{1}$ Institute of Agroforestry, College of Forestry and Natural Resources, University of the Philippines Los Banos. College, Batong Malake, Laguna 4031, \\ Philippines. ”email: ldlandicho@up.edu.ph \\ ${ }^{2}$ Benguet State University. La Trinidad, Benguet 2601, Philippines
}

Manuscript received: 26 April 2021. Revision accepted: 20 June 2021

\begin{abstract}
Landicho LD, Ocampo MTNP, Cabahug RED, Abadillos MG, Cosico RSA, Castillo AKA, Ramirez MAJP, Laruan KA. 2021. Local knowledge and practices towards the ecological restoration of selected landscape in Atok, Benguet, Philippines. Biodiversitas 22: 2785-2794. This study argues that local ecological knowledge and practices contribute to forest conservation and management efforts. This argument is based on the research conducted in upland communities in Atok, Benguet, Philippines. Interviews, farm visits, and focus group discussions revealed that the local communities have been dependent on the forest resources within the watershed in their agricultural production activities. These local communities employed their knowledge and practices towards restoring the ecological state of the watershed. These include the integration of trees on the farm, planting of Alnus japonica for soil and water conservation, the establishment of structural soil and water conservation, maintenance of communal forests, and awareness building among the youth on forest conservation and management.. A very low (0.9718) diversity index and a very high (0.825) evenness index were recorded in the farm lots, while a very low (0.437) diversity index and moderate (0.421) evenness index were measured in the communal forests. On the other hand, high soil organic matter contents of $6.49 \%$ and $5.86 \%$ were recorded both at the community and farm lots, respectively. Results imply the need to sustain the use of local knowledge and practices in combination with the technological interventions from academia and research institutions to enhance the ecological restoration of forest landscapes.
\end{abstract}

Keywords: Communal forests, evenness index, diversity, local communities, soil organic matter

\section{INTRODUCTION}

The Food and Agriculture Organization (FAO) reported that since 1990, about 38.7 million hectares of primary and other naturally regenerated forest have been lost in the Asia-Pacific Region, for which, Southeast Asia has the highest total reductions of about 33.2 million hectares of 7.6 percent of the land area (www.fao.org). As argued by Kanounnikoof and Kongphan-Apirak (2008), international market demand is the main driver for large-scale deforestation for agriculture, while small-scale deforestation is partly driven by market opportunities for smallholder crops such as rubber; landraces to secure property rights; and, social problems such as poverty and population growth.

In the Philippines, Calderon (2013) reported that the total forest area increased from 6.5 million to about 7.2 million ha from 1988 to 2003, while the number of hotspots for illegal timber or logging activities in natural forests was reduced by 78 percent and 86 percent in all provinces and municipalities, respectively. Guiang and Aragon (2016) noted that overall, forest cover in 2010 increased by about 22 percent or more than three percent per annum. They have also cited that forest degradation in the Philippines is caused by logging activities, poverty, and limited economic opportunities.
In response to these concerns, a number of initiatives have been undertaken to restore the forest ecosystem in the Philippines. Government-led and private sector-led initiatives in forest restoration have been on the ground. Partnership agreements and outsourcing arrangements were also instituted with the local government units and communities to help bolster forest restoration. Policy, technical and social approaches were likewise implemented. Higgs (2005) argues that besides scientific restoration requires scientific and technological insights and should put emphasis on the importance of support of local communities, effective policies, appropriate legislation, and long-term funding for durable restoration.

Ecological restoration is the process of assisting the recovery of an ecosystem that has been degraded, damaged, or destroyed as a result of direct or indirect human activities or in some cases caused by natural disturbances (SERI 2004). Local and indigenous communities are always seen as an important component of forest rehabilitation and ecological restoration initiatives. In their article, Egan et al. (2011) argued that human plays an important role in ecological restoration, primarily because they are responsible for environmental degradation, and thus, they are likewise responsible for repairing it. They also recognized the intrinsic knowledge and skills of the indigenous people in ecological restoration, particularly in the areas that they inhabit, Vogt et al. (2002) in Sirima 
(2015) also added that the close linkage between nature and culture, and the long-term interaction with the local environment, provide most of the indigenous communities with a holistic understanding of ecological processes of the environment, and hence, their ability to manage them. Drew (2005) further added that indigenous communities that use traditional knowledge as a conservation mechanism tend to have more long-term efficacy in the management of their resources than their counterpart with top-down approaches.

Despite the perceived utility of indigenous ecological knowledge (IEK) in scientific research, its wider application remains low, which could be because most of the information obtained through IEK is rarely documented as argued by Huntington (2000) in Sirima (2015). In the Philippines, a number of IEK have been documented focus on the qualitative aspect and anecdotes of the indigenous communities as in the case of "imong", "lapat" and "muyung" conservation management practices in Cordillera Administrative Region (Garcia and Naganag 2014; Camacho et al. 2012), "inum-an", "gen-gen”, “dayog", "balkah", kinebbah", and "tuping" among the Ikalahans in Nueva Vizcaya (Camacho et al. 2012).

Uprety et al. (2012) pointed out that despite a growing number of articles published on traditional knowledge, only a few have addressed its contribution to ecological restoration. The potential contribution of traditional ethnoecological knowledge in restoration ecology has not been well studied. As a result, the integration of traditional knowledge in restoration planning remains undervalued in many parts of the world (Mariscal Chávez 2016).
This article highlights the narratives and empirical evidence on the contributions of the knowledge and practices of local communities towards the ecological restoration of selected landscapes in the northern part of the Philippines.

\section{MATERIALS AND METHODS}

The study was conducted in Barangay Caliking and Barangay Topdac in the municipality of Atok, Benguet (Figure 1). The municipality of Atok serves as the headwaters of the Amburayan and Agno River Basin. The local communities that inhabit these villages are mostly "Ibalois" and the rest are "Kankanaeys".

Demographic and socioeconomic information were gathered from the selected research participants using semi-structured interviews. The research team conducted a transect walk to determine the biophysical conditions of the selected landscapes. These include the topography, land uses, and vegetation. The sampling intensity was computed using Slovin's formula:

$$
\mathrm{n}=\mathrm{N} /\left(1+\mathrm{Ne}^{\wedge} 2\right)
$$

Where:

$\mathrm{n}$ : Number of samples

$\mathrm{N}$ : Total population

e : Error tolerance

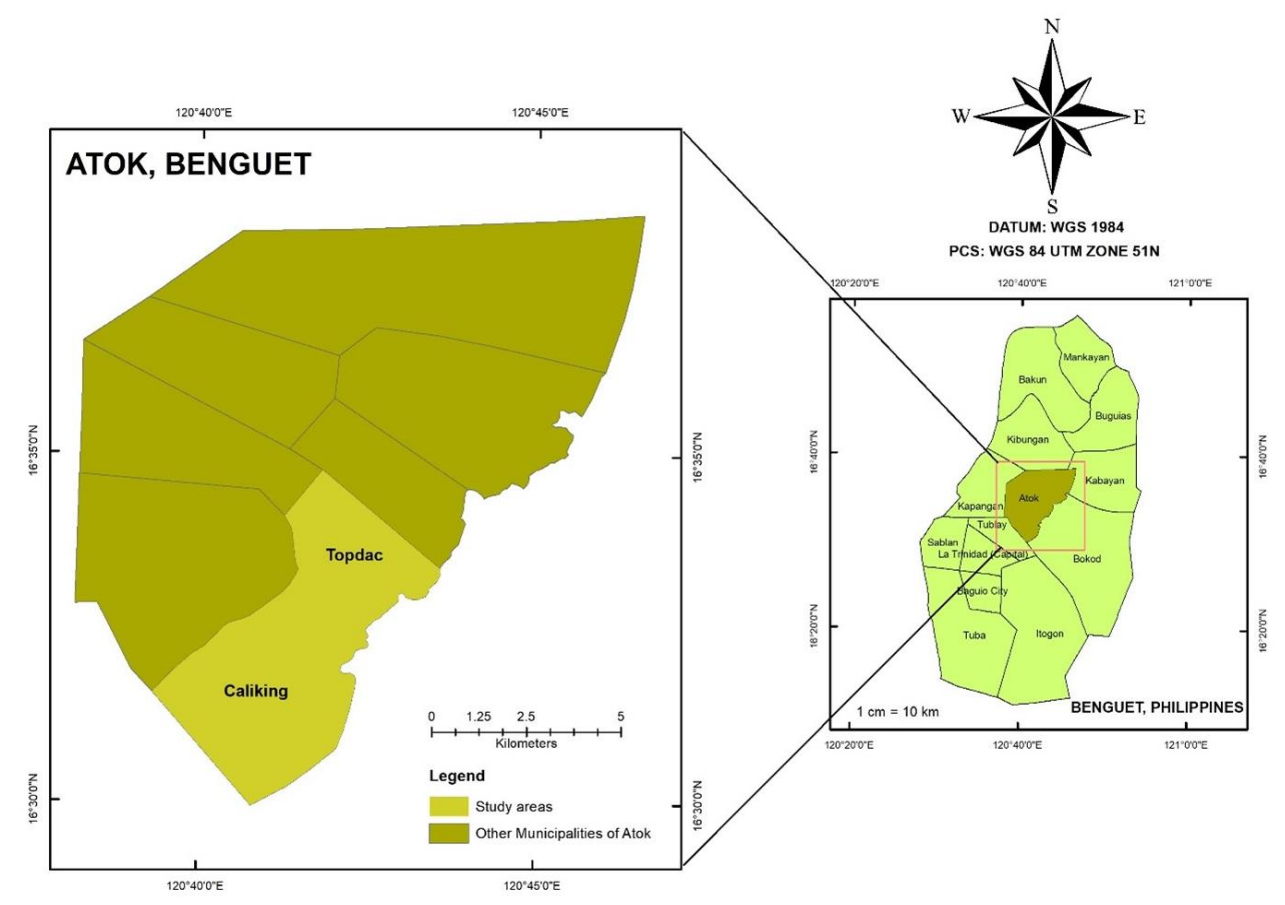

DATA SOURCES: NAMRIA, PHILGIS

Figure 1. Study areas in Atok, Benguet, Philippines 
The research participants were selected using stratified random sampling, with the type of farming system as the stratum. There were five farming systems that exist in the study areas. These include sayote-based agroforestry system, coffee-based agroforestry system, sayote monocropping, vegetable intercropping, and mixed fruit trees. Focus group discussions (FGDs), participated by the elders, key leaders, and selected farmers, were organized across the selected landscape to enrich the information, validate the data generated from the in-depth interview and documentation, and further discuss key issues and concerns. The actual visit to and observation of these indigenous practices were made to enrich the documentation.

Measurements of biological diversity and soil sampling were done in 22 sampling plots, representing 16 plots within the farm lots with a quadrat area of $10 \mathrm{~m} \times 20 \mathrm{~m}$, and six plots in the community forest with a quadrat area of $10 \mathrm{~m} \times 10 \mathrm{~m}$. All existing plant species inside the quadrat plots were identified and recorded. Their taxonomic names and families were determined using available references..

The Importance value (IV) of trees was determined to give an estimate of its influence on the sample farms and in the community forest. The IV was computed through the relative frequency, relative density, and relative dominance of each plant species.

Density $=\frac{\text { Total number of tree individuals counted per species }}{\text { Total area sampled }}$

Relative Density $=\underline{\text { Total number of tree individuals counted per species x } 100}$ Total number of all species

Species Coverage $=(0.7854) \times(\mathrm{DBH})^{2}$ or Basal Area

Relative Dominance $=\underline{\text { Dominance of species } \times 100}$

Total dominance of species

Species Frequency $=$ Number of plots species occur x 100

Total number of plots

Relative Frequency $=\underline{\text { Frequency of species } \mathrm{x} 100}$

Total frequency of all species

Importance Value $=$ Relative Density + Relative Dominance + Relative Frequency

Meanwhile, the Shannon-Weiner diversity index ( $\left.H^{\prime}\right)$ was used to estimate the biological diversity in the area. It could be used to assess the variation of a population of different species in an ecosystem. In addition, Pielou's Evenness Index $(J)$ was used to measure the relative abundance of the different species that make up the plant community.

$$
\mathrm{H}^{\prime}=\sum_{\mathrm{i}=1}-(\mathrm{Pi} * \ln \mathrm{Pi})
$$

Where:

H' : Shannon-Weiner Diversity Index

$\mathrm{P}_{\mathrm{i}}$ : fraction of the entire population made up of species $i$

$S$ : numbers of species encountered/species richness

$\Sigma$ : sum of all species from species 1 to species $S$
Note: The power to which the base e $(\mathrm{e}=$ $2.718281828 \ldots . . .$.$) must be raised to obtain a number is$ called the natural logarithm (ln) of the number.

$\mathrm{J} \quad=\mathrm{H}^{\prime} / \ln (\mathrm{S})$

Where:

J : Pielou's Evenness Index

$\mathrm{H}^{\prime} \quad$ : Shannon-Weiner diversity index $\left(\mathrm{H}^{\prime}\right)$

$\ln (\mathrm{S})$ : natural logarithm of species richness

The diversity index was calculated by dividing the number of individuals of each species found in the sample by the total number of all species (represented by $P$ ), multiplied by the fraction of its natural $\log \left(P_{1} * \ln P_{1}\right)$. This procedure will be repeated for all of the different species. The sum of all the $\left(P_{1} * \ln P_{1}\right)$ represents the value of $H^{\prime}$. This value will then be used to compute for the species evenness index by dividing $H^{\prime}$ by the natural logarithm of species richness of the total number of species encountered $(\ln (S))$. The index was then analyzed using the classification scheme proposed by Fernando (1998).

\section{RESULTS AND DISCUSSION}

\section{Socioeconomic conditions of the local communities in the selected landscapes/watersheds}

The indigenous people that live within the Cordillera mountain range which covers six provinces in the middle of Northern Luzon - Abra, Apayao, Benguet, Ifugao, Kalinga, and Mountain Province are collectively called Igorots, meaning "mountain people" (Molintas 2004). Table 1 shows that the farmers in the study sites were mostly $(67 \%)$ males, with a mean age of 42 years old. These farmers were generally younger as compared to the other upland farming communities whose mean age was recorded at 57 years old (Landicho et al. 2015; Landicho et al. 2016). This could be because the respondents were already second- or third-generation farmers. The farmers were mostly married (84\%) with a mean household size of five (5). The farmers were smallholders as most (72\%) of them managed less than one hectare of a farm, from which they generate an estimated annual income ranging from Php 10000-20000 (US\$ 200-400). Despite the small farm sizes, the majority (64\%) of these farmers, reported ownership over these farms. As such, they have the autonomy to decide the type of crop species to be cultivated as well as the farming systems to employ.

\section{Farm characteristics and land uses}

Table 2 shows that most $(62 \%)$ of the farms cultivated by the farmers have steep slopes and therefore, are prone to soil erosion and landslides. Their sources of irrigation for cropped areas are spring, river, and rainfall. They lack irrigation facilities, and therefore, change in the rainfall pattern significantly affects their crop production. It can be noted that the farmers were generally engaged in the production of vegetables, fruit trees, and livestock. The forest trees were likewise integrated into most of their farms, particularly at the upper portion and along the farm boundaries. 
Table 1. Socioeconomic characteristics of farmers in Atok, Benguet, Philippines

\begin{tabular}{|c|c|c|}
\hline Socioeconomic characteristics & $\begin{array}{c}\text { Frequency } \\
(n=91)\end{array}$ & $\begin{array}{c}\text { Percentage } \\
(\%)\end{array}$ \\
\hline \multicolumn{3}{|l|}{ Sex } \\
\hline Male & 25 & 35 \\
\hline Female & 46 & 65 \\
\hline \multicolumn{3}{|l|}{ Age } \\
\hline$<30$ & 12 & 19 \\
\hline $31-40$ & 12 & 19 \\
\hline $41-50$ & 18 & 28 \\
\hline $51-60$ & 13 & 20 \\
\hline$>60$ & 9 & 14 \\
\hline Mean & \multicolumn{2}{|c|}{42} \\
\hline \multicolumn{3}{|l|}{ Civil status } \\
\hline Single & 5 & 8 \\
\hline Married & 60 & 84 \\
\hline Widow/er & 6 & 8 \\
\hline \multicolumn{3}{|l|}{ Household size } \\
\hline $1-3$ & 16 & 22 \\
\hline $4-6$ & 35 & 49 \\
\hline $7-10$ & 20 & 28 \\
\hline Mean & \multicolumn{2}{|c|}{5} \\
\hline \multicolumn{3}{|c|}{ Estimated annual farm income $($ Php $1=$ US\$ 0.021) } \\
\hline$<$ Php 10000 & 5 & 8 \\
\hline Php 10000-20000 & 25 & 38 \\
\hline Php 21000-30000 & 16 & 25 \\
\hline Php 31000-40000 & 4 & 6 \\
\hline Php 41000-50000 & 1 & 1 \\
\hline >Php 50000 & 14 & 21 \\
\hline
\end{tabular}

There were five types of land uses and farming systems that exist in the two villages. These include a sayote-based agroforestry system with sayote (Sechium edule) as the main crop. This vegetable crop is prominent in the highlands of Cordillera Administrative Region (CAR), because of its suitability to the climatic and other biophysical conditions of the area. There were also farmers who are engaged in a coffee-based agroforestry system, with coffee (Coffea sp.) as the dominant or primary crop. Coffee beans command a higher market price because of a well-established marketing arrangement. This opportunity encouraged the farmers to cultivate this crop. Meanwhile, one village is engaged solely on the monocropping of sayote, while others are engaged in mixed vegetable production and mixed fruit trees.

\section{Biodiversity assessment and soil analysis Species composition}

A total of 105 tree species were found across the 22 sampling plots in the two study areas in Atok, Benguet (Table 3). These identified species consisted of 69 individuals which belong to 10 families, which are found in the communal forest, and 36 species belonging to five families, which are distributed in the individual farms. The data revealed that Pinaceae had the highest number of individuals in the communal forest, while Rubiaceae had the highest in the individual farms. Results indicate that farmers integrate woody perennials in their existing farm plots.
Table 2. Farm characteristics and land uses in the two study areas in Atok, Benguet, Philippines

\begin{tabular}{|c|c|c|}
\hline Farm characteristics & $\begin{array}{c}\text { Frequency } \\
(n=91)\end{array}$ & $\begin{array}{c}\text { Percentage } \\
(\%)\end{array}$ \\
\hline \multicolumn{3}{|l|}{ Topography } \\
\hline Steep & 44 & 65 \\
\hline Rolling & 17 & 25 \\
\hline Flat & 3 & 4 \\
\hline Flat to rolling & 4 & 6 \\
\hline \multicolumn{3}{|l|}{ Source of irrigation } \\
\hline Spring & 4 & 6 \\
\hline River & 37 & 54 \\
\hline Rainfall & 26 & 38 \\
\hline Spring + rainfall & 45 & 66 \\
\hline \multicolumn{3}{|l|}{ Farm components } \\
\hline \multicolumn{3}{|l|}{ Annual crops } \\
\hline Vegetables & 51 & 75 \\
\hline Root crops & 7 & 10 \\
\hline \multicolumn{3}{|l|}{ Fruit trees } \\
\hline Coffee & 33 & 48 \\
\hline Avocado & 24 & 35 \\
\hline Mango & 13 & 19 \\
\hline Lemon & 11 & 16 \\
\hline Banana & 21 & 31 \\
\hline Guava & 2 & 3 \\
\hline Jackfruit & 5 & 7 \\
\hline Papaya & 2 & 3 \\
\hline \multicolumn{3}{|l|}{ Forest trees } \\
\hline Kadasan (Native trees) & 16 & 23 \\
\hline Alnus & 59 & 87 \\
\hline Benguet Pine & 41 & 60 \\
\hline Bamboo & 4 & 6 \\
\hline \multicolumn{3}{|l|}{ Livestock } \\
\hline Swine & 15 & 24 \\
\hline Chicken & 48 & 76 \\
\hline \multicolumn{3}{|l|}{ Land use/Farming system } \\
\hline Sayote monocropping & 13 & 19 \\
\hline Mixed vegetables & 6 & 9 \\
\hline Mixed fruit trees & 7 & 10 \\
\hline Coffee-based agroforestry & 10 & 14 \\
\hline $\begin{array}{l}\text { Sayote+Coffee-based } \\
\text { agroforestry system }\end{array}$ & 31 & 45 \\
\hline
\end{tabular}

\section{Importance value of identified plant species}

Across the sampling plots in the communal forest, Benguet Pine (Pinus insularis) was found to be the most dominant species having the highest Importance Value (IV) of $159.05 \%$ as shown in Table 4. It was followed by Alnus japonica, Thea sinensis, Dracontomelon dao and Camellia lanceolata with $57.40 \%, 14.89 \%, 11.99 \% \%$, and $9.42 \%$ importance values, respectively. At the farm level, on the other hand, Table 6 shows that Benguet pine still dominates the farm lots of the farmers, having an importance value of $106.51 \%$. This is followed by Alnus japonica, Coffea sp., and Persea gratissima with importance values of $84.36 \%, 49.76 \%$, and $29.94 \%$, respectively. The dominance of Benguet pine indicates farmers' preference for this species, as well as the suitability of the species to the existing agroclimatic conditions of the study areas, and the cultural services of the tree species. This finding also supports earlier discussion that Alnus japonica is being maintained in the farm lots because of the perceived soil amelioration characteristics. Meanwhile, coffee is being cultivated in the farm lots because of its economic importance. 
Meanwhile, the Shannon-Wiener diversity index $(\mathrm{H})$ showed that sampling plots across the communal forest and farm lots had a very low biodiversity index of 0.437 and 0.972 , respectively (Table 5). This indicates that only a few species exist in the two study areas. It could be that only these species are well-suited on the agroclimatic and biophysical conditions of the study sites, particularly the woody perennials. Farmers' preference could be another factor such that species with cultural and ecological importance are given due consideration. However, the Pielou's Evenness Index (J) across sampling plots in the farm lots was very high having a value of 0.825 . The same is true with the sampling plots within the communal forest, with a moderate evenness index of 0.421 . This indicates that the species are evenly distributed across the farm lots and communal forest.

Table 6 shows that the soils in the community forests and farm lots were all acidic having a mean soil $\mathrm{pH}$ of 4.02 and 4.05 , respectively. It is noteworthy that there is a high soil organic matter across the sampling plots with average values of $6.49 \%$ in the community forests and $5.86 \%$ in the farm lots. Soil organic matter (SOM) is the organic component of soil, consisting of three primary parts including small (fresh) plant residues and small living soil organisms, decomposing (active) organic matter, and stable organic matter (humus) (www.ncrs.usda.gov). Fageria (2012) mentioned that soil organic matter, an indicator of soil productivity, is crucial in ensuring the sustainability of cropping systems. Community forests have higher soil organic matter content, primarily because these areas are less disturbed as compared to the farm lots. Table 6 also shows that there is no significant difference in the nitrogen levels of soils in community forests and farm lots having average values of $0.32 \%$ and $0.29 \%$, respectively.
Local knowledge and practices towards ecological restoration

The buffer zones within the watershed area in the study area serve as the home and source of livelihoods of the local communities. Results of FGD revealed that while the local communities in Atok, Benguet, implement strategies aimed at striking a balance between their agricultural activities and ecological integrity. As claimed by number literature, the knowledge, innovations, and practices of indigenous and local communities who are in direct contact with nature, play a key role in biodiversity and forest conservation (Colchester et al. 2008; Camacho et al. 2012; Salvana and Arnibal 2019; Gabriel et al. 2020). Among the local knowledge and practice of the local communities in Atok, Benguet is the following:

Table 3. Summary of existing families with the corresponding number of species and individuals in the two study areas in Atok, Benguet, Philippines

\begin{tabular}{lcc}
\hline Family name & $\begin{array}{c}\text { Number of } \\
\text { species }\end{array}$ & $\begin{array}{c}\text { Number of } \\
\text { individuals }\end{array}$ \\
\hline Communal forest & 1 & 4 \\
Anacardiaceae & 1 & 17 \\
Betulaceae & 1 & 1 \\
Cyatheaceae & 1 & 1 \\
Lauraceae & 1 & 1 \\
Malvaceae & 1 & 1 \\
Meliaceae & 1 & 1 \\
Moraceae & 1 & 36 \\
Pinaceae & 1 & 2 \\
Rubiaceae & 2 & 6 \\
Theaceae & & \\
Farm lots & 1 & 11 \\
Betulaceae & 1 & 3 \\
Lauraceae & 1 & 9 \\
Pinaceae & 1 & 12 \\
Rubiaceae & 1 & 1 \\
Anacardiaceae & 1 & 1 \\
Moraceae & & \\
\hline
\end{tabular}

Table 4. Importance value of species across sampling plots in the communal forest and farm lots in the two study areas in Atok, Benguet, Philippines

\begin{tabular}{|c|c|c|c|}
\hline Species & Scientific name & Family name & Importance value (\%) \\
\hline \multicolumn{4}{|c|}{ Communal forest } \\
\hline Alnus & Alnus japonica (Thunb.) Steud. & Betulaceae & 57.40 \\
\hline Benguet Pine & Pinus insularis Endl. & Pinaceae & 159.05 \\
\hline Danglin & Grewia multiflora Juss. & Malvaceae & 6.40 \\
\hline Dao & Dracontomelon dao (Blanco) Merr. & Anacardiaceae & 11.99 \\
\hline Giant fern & Cyathea contaminans (Wall. \& Hook.) Copel. & Cyatheaceae & 6.60 \\
\hline Haikan & Camellia lanceolata (Blume) Seem. & Theaceae & 9.42 \\
\hline Kahoy dalaga & Mussaenda philippica A. Rich & Rubiaceae & 7.83 \\
\hline Kalantas & Toona calantas Merr. \& Rolfe & Meliaceae & 7.09 \\
\hline Marang & Litsea cordata (Jack.) Hook.f. & Lauraceae & 6.37 \\
\hline Opdas & Ficus irisana var. Validicaudata & Moraceae & 6.46 \\
\hline Tsa & Thea sinensis L. & Theaceae & 14.89 \\
\hline \multicolumn{4}{|l|}{ Farms } \\
\hline Alnus & Alnus japonica (Thunb.) Steud. & Betulaceae & 84.36 \\
\hline Avocado & Persea gratissima Gaertn. & Lauraceae & 29.94 \\
\hline Benguet Pine & Pinus insularis Endl. & Pinaceae & 106.51 \\
\hline Coffee & Coffea arabica $\mathrm{L}$. & Rubiaceae & 49.76 \\
\hline Mango & Mangifera indica $\mathrm{L}$. & Anacardiaceae & 13.84 \\
\hline Mulberry & Morus alba $\mathrm{L}$. & Moraceae & 15.57 \\
\hline
\end{tabular}


Table 5. Shannon-Wiener Diversity Index and Pielou's Evenness Index across sampling plots in the two study areas in Atok, Benguet, Philippines

\begin{tabular}{lll}
\hline Main plot & Diversity index & Evenness index \\
\hline Farm lots & 0.9718 (very low) & 0.825 (very high) \\
Communal forest & 0.437 (very low) & 0.421 (moderate) \\
\hline
\end{tabular}

Note: *based on Fernando et al. 1998: 3.50 and above as very high; 3.00-3.49 as high; 2.50-2.99 as moderate; 2.00-2.49 as low; and 1.99 and below as very low

Table 6. Soil analysis from samples gathered from the community forest and farm lots

\begin{tabular}{lcccc}
\hline \multirow{2}{*}{ Area } & \multicolumn{4}{c}{ Mean values of soil fertility indicators } \\
\cline { 2 - 5 } & $\mathbf{p H}$ & $\mathbf{\% O C}$ & $\mathbf{\% O M}$ & $\mathbf{\% \mathbf { N }}$ \\
\hline Community forest $^{1}$ & 4.02 & 3.77 & 6.49 & 0.32 \\
Farmlots $^{2}$ & 4.05 & 3.41 & 5.86 & 0.29 \\
\hline
\end{tabular}

Note: ${ }^{1}$ ) comprised of six sampling plots; ${ }^{2}$ ) comprised of 22 sampling plots

Maintaining Alnus japonica in the farms and composting its litters to enhance soil fertility

To maintain the fertility of the soil, the local communities never cut the Alnus trees (Alnus japonica) within the farms that they cultivate and around the watershed areas (Figure 2). Alnus litters were also collected and utilized as fertilizers. According to the respondents, alnus trees were natural stands and never propagated. The farmers considered these trees as important species, particularly in ameliorating the soil condition. From their observations, vegetable crops that were applied with Alnus compost grow well. Bengwayan (2019) noted that the deep root system of Alnus gives some stability to slopes, and at the same time, restores soil fertility through nitrogen fixation. Besides its ecological function, Alnus trees also served as live posts for sayote, the main vegetable crop of the farmers, and as a shade tree for coffee. In another study, Villamor et al. (2010) noted that integrating Alnus species into the swidden farming in Kalahan Forest Reserve enhances carbon stocks in the area.

\section{Establishment of structural soil and water conservation measures}

The local communities established ripraps and bench terraces for farms with steep slopes (Figures 3 and 4) to control soil erosion, and at the same time, maximizing the land for agricultural production. Surface run-off and soil loss are reduced by rock barriers, hedgerows, and terraces (Dano and Siapno 1992; Bai et al. 2019). Deng et al. (2021) highlighted the contributions of terracing in preventing soil erosion, conserving water, and increasing agricultural production. They further argued that in terms of ecosystem services, terraces reduce runoff and sediment by $41.9 \%$ and $52 \%$, respectively; improve soil moisture content by $12.9 \%$, and contribute toward the conservation of plant biodiversity on a local scale. This finding is validated by Chen et al. (2020) who have observed an average increase of $12.4 \%$ moisture content in the terraced lands in China. However, Dorren and Ray (2004) argued that terracing becomes more efficient if additional conservation practices are employed such as contour plowing, appropriate crop cultivation, and maintaining permanent soil cover.

\section{Integrating trees on the farm}

While many farmers in the study areas were engaged in vegetable production, they have also integrated woody perennials on their farms. These include coffee (Coffea sp.), avocado (Persea americana), lemon (Citrus limon), mango (Mangifera indica), and native forest trees. Figure 5 shows a typical sayote farm with forest and fruit trees along the farm boundaries. Besides serving as a trellis of the vegetables particularly sayote, the woody perennials are also considered as windbreaks. To ensure the availability and accessibility of water sources and supply, the farmers maintain 'kadasan", a collective term for broad-leaf tree species, in their individual farms, regardless of land use (Figure 6). They believed that the "kadasan" serves as water source within the watershed. This local knowledge is validated by science. Besides providing as additional food and income source, trees, in general, provide ecological services, such as carbon sequestration (Casas et al. 2014; Palma and Carandang 2014; Marin et al. 2015; Baliton et al. 2017; Tabal and Mendoza 2020; Sharma et al. 2021), and enhancement of biological diversity (Amoroso et al. 2012; Malabrigo 2013; Baliton et al. 2017).

\section{Conservation of the giant tree fern}

The farmers in the study areas believed that the Giant Tree Fern (Cyathea spinulosa Wall. ex Hook.), shown in Figure 7 , provides them a steady supply of water in the river system and springs. Hence, these ferns are maintained and are not cut by the farmers. Thapa et al. (2017) highlighted that tree fern provides four types of ecosystem services, namely provisioning, regulating, supporting, and cultural services. The leaves and trunks are used directly by humans, while young fronds are used as food, fodder, and fiber. It also plays a significant role in the ecosystem functioning in the canopy and forest floors (Hill and Silander 2001). Giant tree ferns are reportedly on the threatened status in many parts of the world, particularly in India (Das et al. 2013). Amoroso et al. (2012) specifically found out that there are 32 rare species, one endangered species, seven depleted species; 89 endemic species, and 81 economically important species of Pteridophytes in the Philippines. Meanwhile, Fernando et al. (2008) reported that around 202 taxa of Pteridophytes are on the list of threatened plant species in the Philippines. Thus, the efforts of the farmers in conserving the Giant Tree Ferns contribute to the protection and conservation of this species.

\section{Community tree planting}

Besides the local practices being employed by the individual farmers, the village governments of the two study sites also take effort towards ecological restoration. They organize a yearly clean-up of the river system and tree planting activities. The seedlings were mostly given by the Department of Environment and Natural Resources (DENR). The local communities maintain a communal forest. The communal forest houses a number of indigenous tree species. Furthermore, the village leaders 
have executed local ordinances to regulate the cutting of trees. Cutting trees for cultural purposes, particularly for making coffins, is inevitable because of the indigenous beliefs of the local communities. However, cutting of trees for coffins is now being regulated, such that for every tree that is cut, there is a corresponding 10 seedlings for replanting to compensate for the loss of one tree.

\section{Awareness-raising among youth}

The elders believed that the younger generation should be educated about the need for ecological restoration and the local practices that contribute to ecological restoration. The village leaders conduct regular awareness seminars for the elementary students to provide them an overview of sustainable natural resources management using their local practices. The farmer-respondents also encouraged their children to participate in farm development activities not only to develop their appreciation in farming but also to inculcate unto them that upland farming coupled with proper conservation of the natural resources could be a sustainable livelihood.

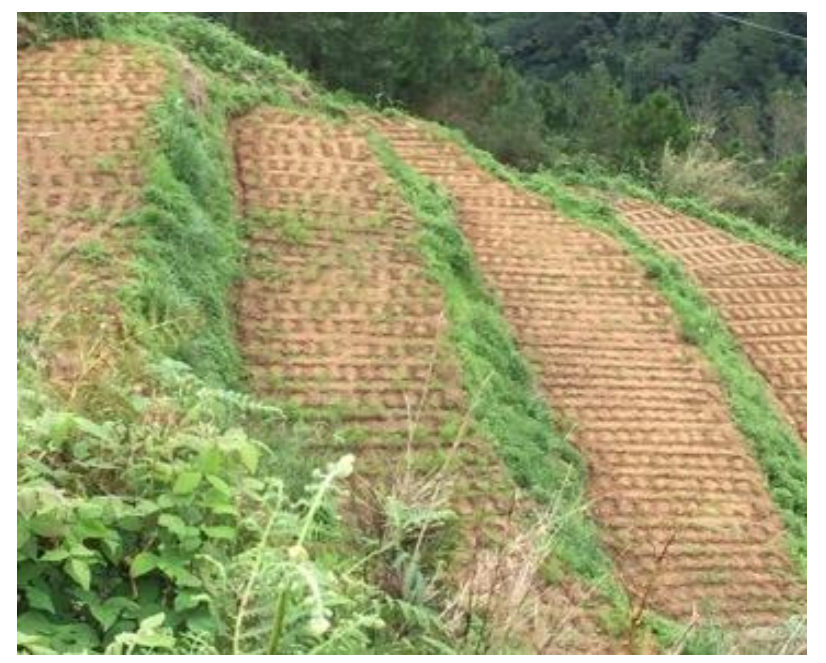

Figure 3. Establishment of terraces along the steep slopes to prevent soil erosion

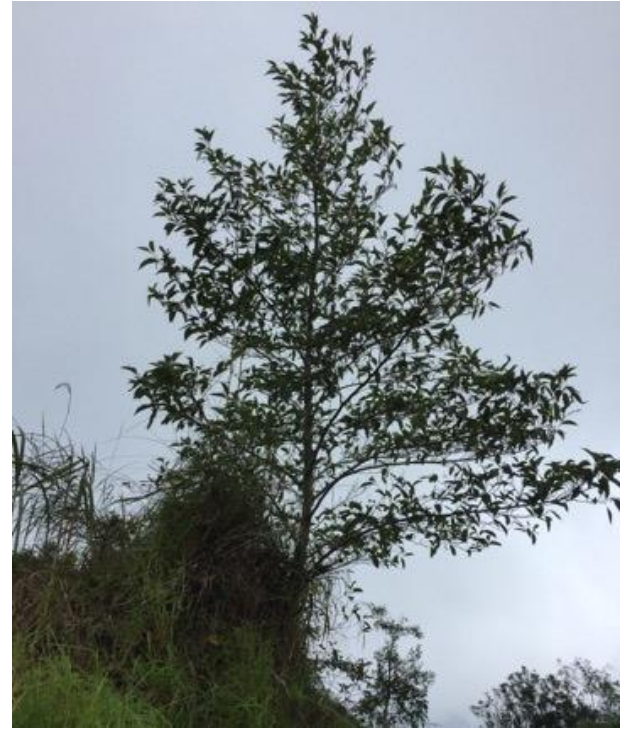

Figure 2. Alnus japonica enhances soil fertility as observed by the farmers

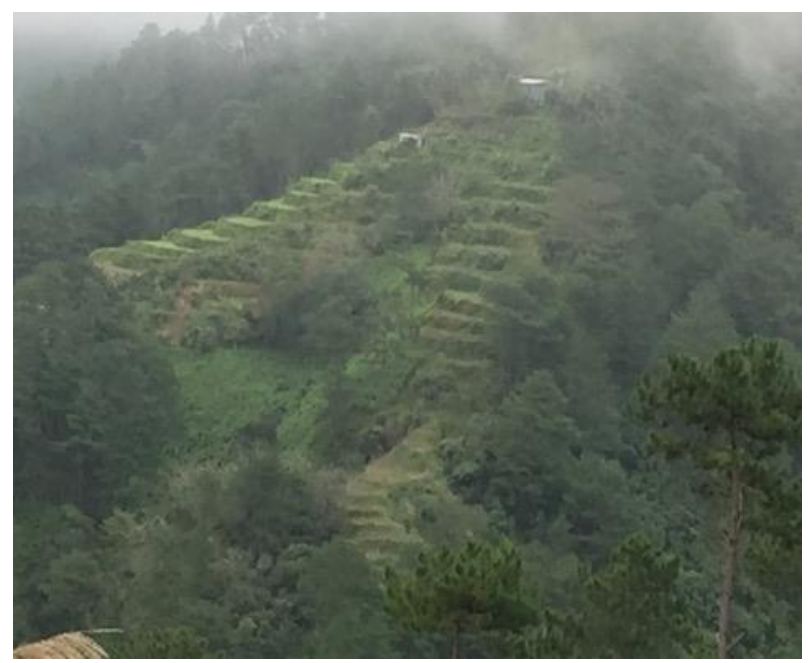

Figure 4. One of the soil and water conservation measures is the establishment of bench terraces to arrest soil erosion

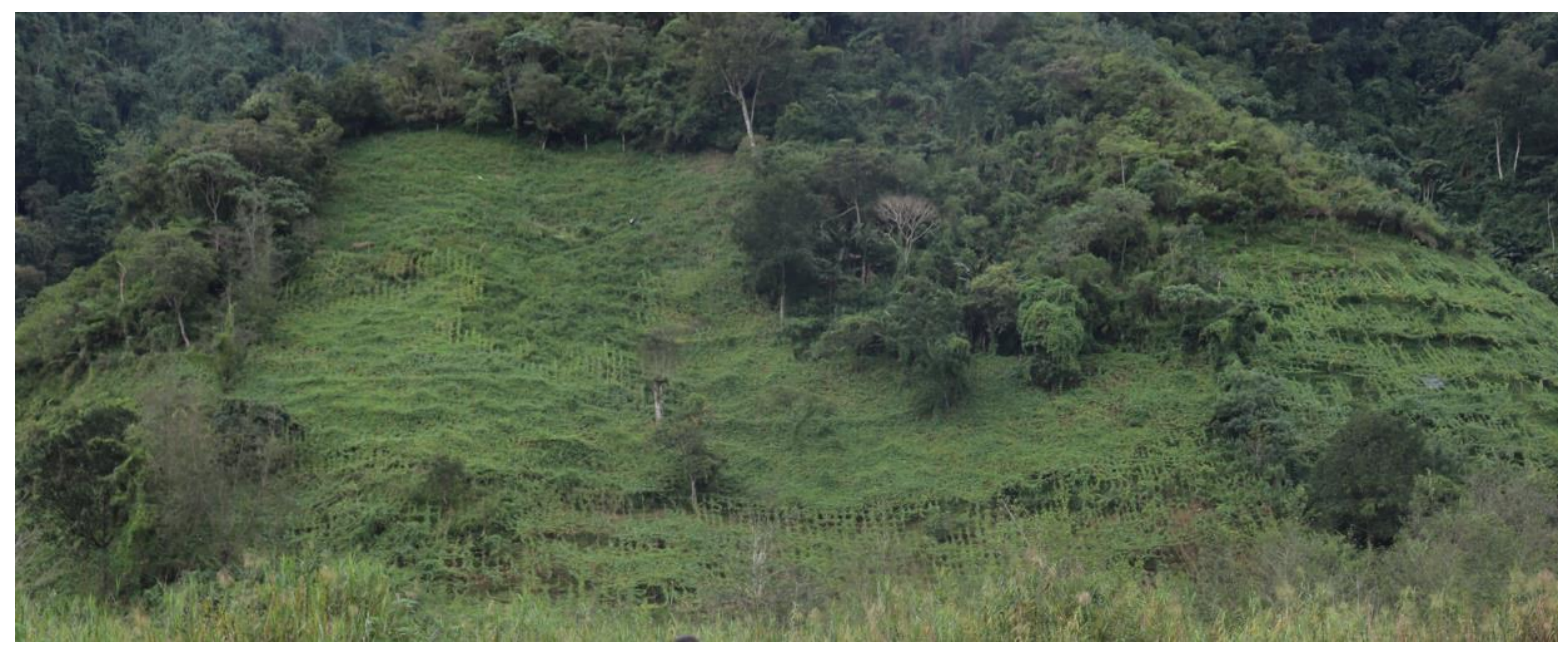

Figure 5. Woody perennials are found along the farm boundaries to prevent soil erosion and to serve as windbreaks 

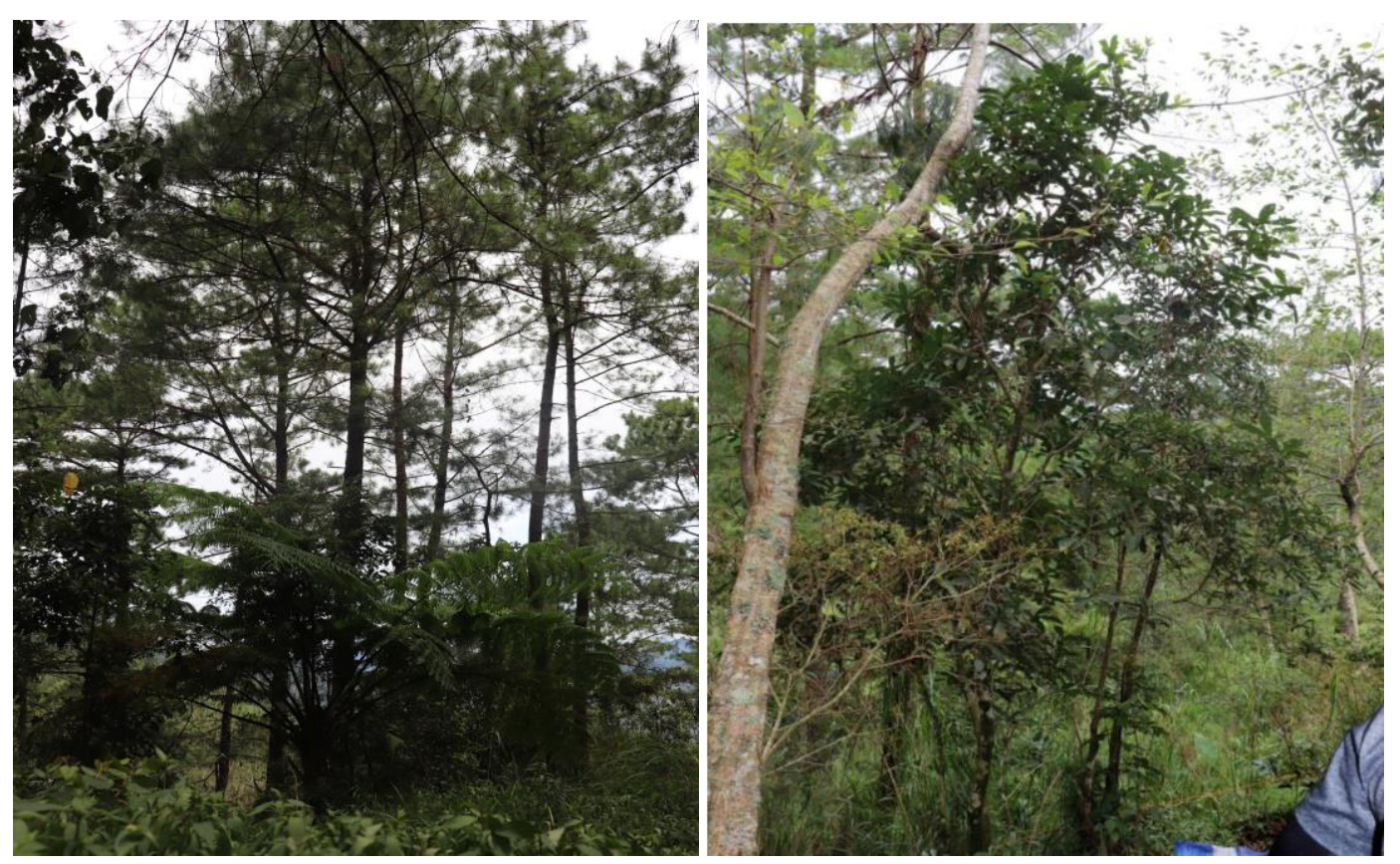

Figure 6. Communal forest being managed by the village government in Topdac, Atok, Benguet, Philippines
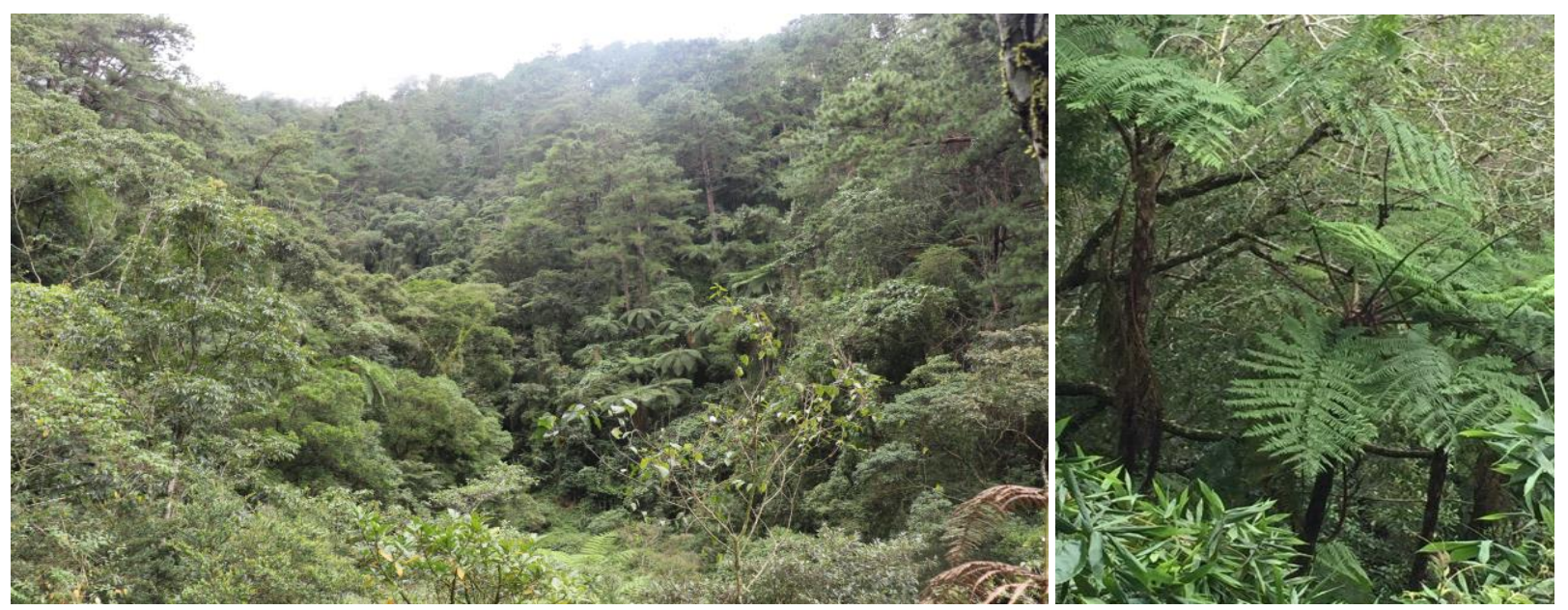

Figure 7. Giant tree fern (Cyathea spinulosa)

\section{Conclusion and recommendation}

Research results indicated that the local communities in Atok, Benguet have developed a nexus of agriculture production and ecological restoration. Their agricultural production which provides for their economic needs is stitched with the ecological environment. These local communities employed their knowledge and practices towards restoring the ecological state of the watershed. These included the integration of trees on the farm, planting of Alnus japonica for soil and water conservation, the establishment of structural soil and water conservation, maintenance of communal forests, and awareness building among the youth on forest conservation and management. A very low (0.9718) diversity index and a very high
(0.825) evenness index were recorded in the farm lots, while a very low (0.437) diversity index and moderate (0.421) evenness index were measured in the communal forests. On the other hand, a high soil organic contents of $6.49 \%$ and $5.86 \%$ were recorded both at the community and farm lots, respectively. Results imply the need to sustain the use of local knowledge and practices in combination with the technological interventions from academia and research institutions to help enhance the ecological restoration of forest landscapes. 


\section{ACKNOWLEDGEMENTS}

The authors would like to acknowledge the farmers, barangay leaders, and elders in Barangays Caliking and Topdac in Atok, Benguet who served as the research participants in the interview and focus group discussion. The village leaders are also recognized for providing consent to the researchers to undertake the study in the two barangays. The Benguet State University, through Dr. Kenneth A. Laruan is also acknowledged for assisting in the field coordination. Finally, the authors would like to thank SEAMEO-BIOTROP for providing funds to carry out this study.

\section{REFERENCES}

Amoroso VB, Amoroso CB, Coritico FB. 2012. Diversity and status of plants in three mountain ecosystems in Southern Mindanao, Philippines. Asian J Biodivers 3: 50-73. DOI: 10.7828/ajob.v3i1.83.

Bai J, Yang S, Zhang Y, Liu X, Guan Y. 2019. Assessing the impact of terraces and vegetation on runoff and sediment routing using the timearea method in the Chinese Loess Plateau. Water 11 (4): 803. DOI: 10.3390/w11040803.

Baliton RS, Wulandari C, Landicho LD, Budiono P, Herwanti S, Rusita R, Paelmo R, Cabahug RE, Comia RA, Visco RA, Castillo AK. 2017. Ecological services of agroforestry landscapes in selected watershed in Indonesia and the Philippines. Biotropia 24 (1): 71-84. DOI: 10.11598/btb.2017.24.1.621

Bengwayan MA. 2019. Alnus tree-based agroforestry saves land, food, biodiversity - OpEd. www.eurasiareview.com/28102019-alnus-treebased-agroforestry-saves-land-food-biodiversity-oped/

Calderon R. 2013. Forest and forestry in the Philippines: 2016 And Beyond. FMB, Quezon City.

Camacho LD, Combalicer MS, Yeo-Chang Y, Combalicer EA, Carandang AP, Camacho SC, de Luna CC, Rebugio LL. 2012. Traditional fores conservation knowledge/technologies in the Cordillera, Northern Philippines. For Policy Econ 22 (2012): 3-8. DOI: 10.1016/j.forpol.2010.06.001

Casas JA, Marin RA, Toledo-Bruno AG, Lacandula L, Aguinsatan R. 2014. Ecosystem Ssrvices of agroforestry model farms in Bukidnon, Philippines. Philippine J Agrofor 2014 (1): 49-72.

Chen D, Wei W, Chen L. 2020. How can terracing impact on soi moisture variation in China? A Meta-Analysis. Agric Water Manag. DOI: 10.1016/j.agwat.2019.105849.

Colchester M, Ferrari MF, Nelson J, Kidd C, Zaninka P, Venant M, Regpala L, Balawag GT, Motin B, Lasimbang B. 2008. Conservation and indigenous peoples: Assessing the progress since Durban. Forest Peoples Programme, Moreton-in-Marsh (Draft report), http://www. forestpeoples.

org/documents/conservation/wcc_conservation_and_ips_interim_rep_ sept08_eng. pdf.

Dano AM, Siapno FE. 1992. The effectiveness of soil conservation structures in steep cultivated mountain regions of the Philippines. Walling DE, Davies TRH, Hasholt B (eds.) Erosion, Debris flows and Environment in Mountain Regions. IAHS Publ 209: 399-405.

Das S, Choudhury MD, Mazumder PB. 2013. In vitro propagation of Cyathea gigantean: A tree fern. Intl J Recent Sci Res 4 (3): 221-224.

Deng C, Zhang G, Liu Y, Nie X, Li Z, Liu J, Zhu D. 2021. Advantages and disadvantages of terracing: A comprehensive review. Int Soil Water Conserv Res. DOI: 10.1016/j.iswcr.2021.03.002

Dorren L, Rey F. 2004. A Review of the effect of terracing on erosion. In: Boix-Fayons C, Imeson A (eds.). Briefing Papers of the 2nd SCAPE Workshop. Soil Conservation and Protection for Europe, Brussel.

Drew JA. 2005. Use of traditional ecological knowledge in marine conservation. Conserv Biol 19 (4): 1286-1293. DOI: 10.1111/j.15231739.2005.00158.x

Egan D, Hjerpe EE, Abrams J. 2011. Why people matter in ecological restoration. In: Egan D, Hjerpe EE, Abrams J (eds) Human Dimensions of Ecological Restoration. Society for Ecological
Restoration. Island Press, Washington, DC. DOI: 10.5822/978-161091-039-2_1.

Fageria NK. 2012. Role of soil organic matter in maintaining sustainability of cropping systems. Commun Soil Sci Plant Anal 43 (16): 2012. DOI: 10.1080/00103624.2012.697234.

Fernando ES 1998. Forest formations and flora of the Philippines: Handout in FBS 21. UPLB, Philippines.

Fernando ES, Co LD, Lagunzad DA, Gruezo WSM, Barcelona JF, Madulid DA, Lapis AB, Texon GI, Manila AC, Zamora PM. 2008. Threatened plants of the Philippines: A preliminary assessment. Asia Life Sci Suppl 3: 1-52

Gabriel AG, de Vera M, Antonio MA. 2020. Roles of indigenous women in forest conservation: A comparative analysis of two indigenous communities in the Philippines. Cogent Soc Sci 6: 2020. DOI: 10.1080/23311886.2020.1720564.

Garcia MAA, Naganag EM. 2014. Forest domain conservation management practices and beliefs of indigenous peoples of the Cordillera Region, Philippines. UNP Res J 23 (1): 124-136.

Guiang ES, Aragon R. 2016. Forest restoration at the landscape level in the Philippines. In: Appanah S (eds.). Forest Landscape Restoration in Asia-Pacific Forests. FAO-RECOFTC, Bangkok, Thailand.

Higgs E. 2005. The two-culture problem: ecological restoration and the integration of knowledge. Restor Ecol 13 (1): 159-164. DOI: 10.1111/j.1526-100X.2005.00020.x.

Hill JD, Silander J. 2001. Distribution and dynamics of two ferns: Dennstaedtia punctilobula Hardwoods-Hemlock Forest. Am J Bot 88 (5): 894-902. DOI: $10.2307 / 2657041$.

Huntington HP. 2000. Using traditional ecological knowledge in science: methods and applications. Ecol Appl 10 (5): 1270-1274. DOI: 10.1890/1051-0761(2000)010[1270:UTEKIS]2.0.CO;2.

Kanounnikoff SW, Kongphan-Apirak M. 2008. Reducing forest emissions in Southeast Asia: A review of land-use change and how payments for environmental services (PES) schemes can affect them. CIFOR, Bogor.

Landicho L, Paelmo R, Cabahug R, de Luna C, Visco R, Tolentino L. 2016. Climate change adaptation strategies of smallholder agroforestry farmers in the Philippines. J Environ Sci Manag 19 (1): $37-45$.

Landicho LD, Visco RG, Paelmo RF, Cabahug RD, Baliton RS, Espaldon ML, Lasco RD. 2015. Field-level evidences of climate change and coping strategies of smallholder farmers in Molawin-Dampalit subwatershed, Makiling forest reserve, Philippines. Asian J Agric Dev 12 (1362-2016-107736): 81-94.

Malabrigo PL. 2013. Vascular flora of the tropical montane forests in Balbalasang-Balbalan National Park, Kalinga Province, Northern Luzon, Philippines. Asian J Biodivers 4 (1). DOI: 10.7828/ajob.v4i1.294.

Marin RA, Casas JV, Aguinsatan RG. 2015. Carbon sequestration assessment of an alley cropping system in Bukidnon, Philippines. Philippine J Agrofor 2 (1): 19-30.

Mariscal Chávez AG. 2016. Local baseline knowledge for conservation and restoration of degraded ecosystems in Ecuador 2016. [Dissertation]. Acta Universitatis Agriculturae Sueciae, SLU, Upsalla, Sweden.

Molintas JM. 2004. The Philippine indigenous peoples' struggle for land and life: challenging legal texts. Ariz J Intl Comp L 21: 269.

Palma RA, Carandang WM. 2014. Carbon sequestration and climate change impact on the yield of Bagras (Eucalyptus deglupta Blume) in bagras-corn boundary planting agroforestry system in Misamis Oriental and Bukidnon, Philippines. J Environ Sci Manag 17 (2): 2937.

Salvana FR, Arnibal SL. 2019. Importance of indigenous communities' knowledge and perception in achieving biodiversity conservation: A case study from Manobo tribe of Southern Mindanao, Philippines. $\begin{array}{lllll}\text { Asian J Ethnobiol } 2 & \text { (2): 54-61. DOI: }\end{array}$ 10.13057/asianjethnobiol/y020203.

Sharma A, Tiwari KN, Bhadori PBS. 2011. Effect of land use land cover change on soil erosion potential in an agricultural watershed. $\mathrm{J}$ Environ Monit Assess 173: 789-801. DOI: 10.1007/s10661-0101423-6

Sirima A. 2015. The Contribution of indigenous ecological knowledge in conservation of Enguserosambu Community Forest, Tanzania.

Society for Ecological Restoration International. 2004. The SER international primer on ecological restoration. Science \& Policy Working Group, October 2004. 
Tabal EP, Mendoza TC. 2020. Accounting the net carbon sequestered of various agroforestry systems (AFSs) in Zamboanga City, Philippines. Intl J Agric Technol 16 (2): 457-474.

Thapa I, Lekhak K, Budha P, Kalu S. 2017. Community-based tree fern conservation strategy: With special reference to Panchase Region. Rufford, UK.

Uprety Y, Hugo A, Bergeron Y, Doyon F, Bouche JF. 2012. Contribution of traditional knowledge to ecological restoration: Practices and applications. Ecoscience 19: 3. DOI: 10.2980/19-3-3530
Villamor GB, Pampolina N, Forcadilla R, Bugtong N, Alano J, Rice D, Omas T, Castillo R, Pulan D. 2010. Rapid Carbon Stock Appraisal: Kalahan, Nueva Vizcaya. Philippines. Working Paper 106, World Agroforestry Centre (ICRAF) Southeast Asia Program, Bogor, Indonesia. [Indonesian]

Vogt KA, Beard KH, Hammann S, Palmiotto JO, Vogt DJ, Scatena FN, Hecht BP. 2002. Indigenous knowledge informing management of tropical forests: the link between rhythms in plant secondary chemistry and lunar cycles. AMBIO: A J Human Environ 31 (6): 485490. DOI: 10.1579/0044-7447-31.6.485. 